\title{
Experimental non-steroidal anti-inflammatory drug-induced enteropathy in the rat: similarities to inflammatory bowel disease and effect of thromboxane synthetase inhibitors
}

\author{
A K Banerjee, $\mathrm{T}$ J Peters
}

\begin{abstract}
We have validated an established animal model of acute inflammatory bowel disease in indomethacin-treated rats. Studies in both in vitro and in vivo ${ }^{51}$ chromium-labelled ethylenediamine tetra-acetate $\left({ }^{51} \mathrm{Cr}\right.$-EDTA) permeability and tissue myeloperoxidase activity, a marker of inflammatory cell invasion, showed increased permeability and enzyme levels, respectively, in treated animals compared to controls (in vitro ${ }^{51} \mathrm{Cr}$-EDTA permeability: (mean (SE)) control $0.10(0.02)$ $\mu \mathrm{l} / \mathrm{mg}$ per tissue, experimental $0.17(0.02)$ ( $p<0.01,2$ way analysis of variance); in vivo ${ }^{51}$ Cr-EDTA permeability: control $3.9(1.3)$ (\% dose recovered), experimental 12.1 (1.5) $(\mathrm{p}<0.01)$; tissue myeloperoxidase: control $10.8(0.4) \mathrm{mU} / \mathrm{mg}$, experimental $17.2(0.5)$ $\mathrm{p}<0.01$ ). Pretreatment or simultaneous treatment of indomethacin-treated animals with glucocorticoids, sulphasalazine, or tetracycline reduced the permeability changes and the tissue inflammatory response (in vitro ${ }^{51} \mathrm{Cr}$-EDTA permeability: (mean (SE)) sulphasalazine+indomethacin $0 \cdot 11(0 \cdot 2)$ $\mu \mathrm{l} / \mathrm{mg}$ tissue $(\mathbf{p}<0.01)$, prednisolone \pm indomethacin $\quad 0.12 \quad(0.02) \quad(\mathbf{p}<0.01)$

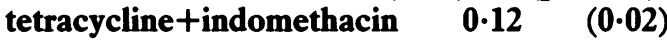
$(\mathbf{p}<\mathbf{0 . 0 1}))$. Glucocorticoids and sulphasalazine, but not tetracycline, administered after the indomethacin also partially corrected the permeability and inflammatory changes induced by indomethacin (in vitro ${ }^{51} \mathrm{Cr}$-EDTA permeability: sulphasalazine $0.15(0.02) \mu \mathrm{l} /$ $\mathrm{mg}, \mathrm{p}<0.02$; prednisolone $0.12(0.02) \mu \mathrm{l} / \mathrm{mg}$, $p<0.01)$. This approach was used to investigate the effects of two different thromboxane synthetase inhibitors in indomethacin-treated animals. Simultaneous treatment with thromboxane synthetase inhibitors and indomethacin prevented the ${ }^{51} \mathrm{Cr}$-EDTA permeability and tissue myeloperoxidase increases induced by indomethacin alone (in vitro ${ }^{51} \mathrm{Cr}$-EDTA permeability: thromboxane synthetase inhibitors+indomethacin 0.11 (0.01) $\mu \mathrm{l} / \mathrm{mg}$ (p0.01); tissue myeloperoxidase: $11(0.4) \mathrm{mU} / \mathrm{mg}$, (p<0.01). Thromboxane synthetase inhibitors administered after the indomethacin also partially corrected the permeability and inflammatory changes induced by indomethacin (in vitro ${ }^{51} \mathrm{Cr}$-EDTA permeability: thromboxane synthetase inhibitors $0.12(0.02) \mathrm{mU} / \mathrm{mg}(\mathrm{p}<0.01)$; tissue myeloperoxidase $13.8(0.5)(\mathrm{p}<0.01)$. These studies indicate that thromboxane synthetase inhibitors partially correct the intestinal lesion non- steroidal anti-inflammatory drug enteropathy, and may therefore be of use in inflammatory bowel diseases in humans.

Non-steroidal anti-inflammatory drug (NSAID) enteropathy is a recently recognised lesion of the alimentary tract characterised in its chronic form by strictures and a chronic enteritis. ${ }^{1}$ Recent work, however, indicates that these lesions are the end result of a disease process, of which local permeability changes are the earliest detectable abnormalities. ${ }^{2}$ The trigger factor for these changes is unknown but the pathogenesis of the lesion may involve alterations in intestinal wall blood flow. ${ }^{3}$ It has been proposed that the fissures, strictures, and fistulas seen in Crohn's disease may represent the end result of a disease process of which local permeability changes in the small intestine are the earliest detectable abnormality. ${ }^{45}$ That increased intestinal permeability may have an aetiological role in Crohn's disease is supported by findings of increased intestinal permeability not only in patients with established disease ${ }^{6}$ but also in their first degree relatives who apparently appear clinically normal.?

NSAID administered chronically to humans and acutely to the experimental animal produces an enteropathy with striking clinical functional and pathological similarities to the chronic inflammatory enteritis seen in Crohn's disease. ${ }^{28}$ We assessed in a rat model of NSAID enteropathy mucosal permeability and inflammatory changes. ${ }^{2}$ In addition, the potential beneficial effects of glucocorticoids, sulphasalazine, and tetracycline were investigated. Since some of the changes may be mediated by local changes in the lipoxygenase/cyclo-oxygenase pathway, ${ }^{10}$ we also studied the effect of two thromboxane synthetase inhibitors on intestinal permeability, inflammatory cell response, and tissue histology.

\section{Methods}

All reagents were from Sigma Chemicals or BDH Chemical Co Ltd (Poole, Dorset). Radiochemicals were obtained from Amersham International (Amersham, Bucks).

ANIMALS

Five week old male Sprague Dawley rats (140$160 \mathrm{~g}$ ) were used throughout. They were fed a standard rodent diet (Labsure LAD 1 Diet, Manea, Cambs). A 'run-in' period was used to
Biochemistry, King's College Hospital, A K Banerjee T J Peters Correspondence to: Mr A K Banerjee. 
determine daily food consumption to allow accurate administration of powdered indomethacin admixed in the diet: the rats were fed using hoppers which recorded the amounts of feed

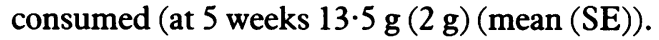

\section{EXPERIMENTAL ENTEROPATHY}

The rats were fed indomethacin $8 \mathrm{mg} / \mathrm{kg}$ body weight for three days in the standard diet using the procedures outlined above. Subsequently, standard diet was provided ad libitum for between one and 42 days. At three day intervals the daily food consumption and the animal weights were recorded. At the end of the experimental period in vivo ${ }^{2}$ and in vitro ${ }^{11}{ }^{51}$ chromiumlabelled ethylenediamine tetra-acetate ${ }^{(51} \mathrm{Cr}$ EDTA) intestinal permeability was determined. Samples of small intestine were taken for histological examination and myeloperoxidase ${ }^{15}$ assays.

\section{IN VITRO ${ }^{\text {S1 }} \mathrm{Cr}$-EDTA PERMEABILITY ${ }^{11}$}

The animals were anaesthetised with methoxyflurane (ICI Pharmaceuticals) and sacrificed by cervical dislocation. A piece of ileum $20 \mathrm{~cm}$ proximal to the ileocaecal valve was cut longitudinally and sectioned into fragments $(5-15 \mathrm{mg}$ wet weight). Jejunum $15 \mathrm{~cm}$ distal to the pylorus in indomethacin-treated animals was also sectioned and ${ }^{51} \mathrm{Cr}$-EDTA in vitro permeability estimated in order to localise the specificity of the response to the ileum. After a brief rinse in buffered HEPES ( $\mathrm{N}$-2-hydroyethane piperazine $\mathrm{N}$-2 ethane sulphonic acid)-oxygenated medium ( $16 \mathrm{mmol} / 1 \mathrm{HEPES}-\mathrm{KOH}, 125 \mathrm{mmol} / \mathrm{l} \mathrm{NaCl}, 3 \cdot 5$ $\mathrm{mmol} / 1 \mathrm{KCl}, 1 \mathrm{mmol} / 1 \mathrm{CaCl}_{2}, 10 \mathrm{mmol} / 1 \mathrm{MgSO}_{4}$, $\mathrm{pH} 7 \cdot 4$ ), the fragments were incubated at $37^{\circ} \mathrm{C}$ for five minutes in an identical medium $(5 \mathrm{ml})$ containing ${ }^{51} \mathrm{Cr}$-EDTA as a permeability marker. The reaction was terminated by blotting and rinsing the fragments for five seconds in ice cold HEPES medium. The tissue samples were reblotted, weighed, and counted for ${ }^{51} \mathrm{Cr}$-EDTA in a LKB Wallac 1280 gammacounter. The ${ }^{51} \mathrm{Cr}$ EDTA permeability was expressed as $\mu \mathrm{l}$ medium/mg tissue.

\section{IN VIVO ${ }^{\text {S1 }} \mathrm{Cr}$-EDTA PERMEABILITY ${ }^{2}$}

The animals were anaesthetised with midazolam (ICI Pharmaceuticals), then $1 \mathrm{ml}$ of water containing $2 \mu \mathrm{Ci}{ }^{51} \mathrm{Cr}$-EDTA (approximately 10 nmol) followed by $1 \mathrm{ml}$ of water were administered by gavage. The nasogastric tube was withdrawn and the animal placed in an individual metabolic cage. Five hours later the urine and stool were collected separately and the animals were anaesthetised with methoxyflurane and sacrificed by cervical dislocation. The abdomen was opened and the bladder emptied by needle puncture. The urine obtained was mixed with that excreted during the five hour test period. Double ligatures were placed at the oesophagogastric junction, the pylorus, $20 \mathrm{~cm}$ distal to the pylorus, terminal ileum $(10 \mathrm{~cm}$ proximal to the ileocaecal valve), and caecocolonic junction. The stomach, proximal and distal small bowel, caecum, and colon were removed and placed in a container and disinfectant (Chloros $\mathbf{R}$ Womersley Boome Chemicals Ltd, Essex) added up to $25 \mathrm{ml}$. Urine and faeces were processed similarly. Each sample was placed centrally between two detectors, set at minimal separation in a bulk sample gammacounter, and counted for $100 \mathrm{sec} .^{12}$ The minimum detectable activity was $0.01 \%$ of the administered dose. The residual carcases were counted in the same counter at minimal possible detector separation. The relative roles of in vitro and in vivo ${ }^{51} \mathrm{Cr}$-EDTA permeability are considered later.

MYELOPEROXIDASE ASSAY (EC 1.11.1.17) ${ }^{15}$

The mucosa was removed from the intestine, blotted dry, and weighed. After suspension in $0.5 \%$ hexadenyltrimethylammonium bromide (HTAB) in ice cold $50 \mathrm{mM}$ phosphate buffer it was homogenised with Polytron homogeniser and centrifuged at $40000 \mathrm{~g}$ in an MSE SS75 centrifuge for five minutes at $4^{\circ} \mathrm{C}(\mathrm{pH}=6 \cdot 0$, $5.0 \mathrm{ml} \mathrm{HTAB} / \mathrm{g}$ tissue). The supernatant was assayed for myeloperoxidase spectrophotometrically. The test sample $(0 \cdot 1 \mathrm{ml})$ was mixed with $2 \cdot 9 \mathrm{ml}$ of $50 \mathrm{mM}$ phosphate buffer $(\mathrm{pH}, 6 \cdot 0)$ containing $0.167 \mathrm{mg} / \mathrm{ml}$ o-dianisidine dihydrochloride (Sigma Chemical) and $0.0005 \%$ hydrogen peroxide. The change in absorbance was measured at $460 \mathrm{~nm}$ for one minute at $25^{\circ} \mathrm{C}$.

\section{STEROID AND SULPHASALAZINE TREATMENT}

Animals were fed an indomethacin-containing diet $(8 \mathrm{mg} / \mathrm{kg}$ per day) for three days and then a normal diet for periods from one to 28 days. At the end of the experimental period prednisolone $(0.5 \mathrm{mg} / \mathrm{kg}$ per day) or sulphasalazine $(20 \mathrm{mg} / \mathrm{kg}$ per day) was administered to groups of animals for three days. The day after the last dose of steroid or sulphasalazine, ${ }^{51} \mathrm{Cr}$-EDTA in vivo and in vitro permeabilities were measured. To ensure that a typical macroscopical lesion had developed in individual animals, immediately before the steroid or sulphasalazine treatment a limited laparotomy was performed and the jejunum and colon inspected for inflammation, thickening, or strictures. Animals in which no macroscopical lesion was seen were excluded from the remainder of the experiment as well as animals with perforations. In addition, some animals were given steroid or sulphasalazine alone and others steroid or sulphasalazine simultaneously with indomethacin.

\section{TETRACYCLINE TREATMENT}

Animals were fed indomethacin $(8 \mathrm{mg} / \mathrm{kg}$ per day) for three days and a normal diet for one to 28 days. Groups of animals were fed tetracycline (25 mg/kg per day) for three days immediately before the indomethacin treatment, tetracycline simultaneously with indomethacin, or tetracycline seven days after the indomethacin treatment, a limited laparotomy having been performed in this last group to ensure that enteropathy had developed. The day after the last dose of tetracycline, ${ }^{\text {sI }} \mathrm{Cr}$-EDTA in vivo and in vitro permeabilities were measured and histological assessments made as above. 
THROMBOXANE SYNTHETASE INHIBITOR STUDIES

Five week old male Sprague Dawley rats (140 $160 \mathrm{~g}$ ) were used throughout. They were fed a standard rodent diet (Labsure LAD 1 Diet, Manea, Cambs). Rats were fed indomethacin $8 \mathrm{mg} / \mathrm{kg}$ admixed with the diet for three days. The presence of lesions was confirmed by limited laparotomy and the animals received a normal diet for periods from one to 28 days.

Further groups of animals received thromboxane synthetase inhibitors, either dazmegrel (3-(IH-Imidazol - 1 -yl-methyl)-2 - methyl-IHindole-1-propanoic acid) administered in a normal diet at $25 \mathrm{mg} / \mathrm{kg}$ per day or UK 49883 (3methyl-2-(3-pyridinylmethyl-benzo [b] throphene-5-carboxylic acid) (Pfizer Ltd, Sandwich, UK), administered in a normal diet at $2.5 \mathrm{mg} / \mathrm{kg}$ per day. ${ }^{114}$ Animals were also fed indomethacin and the thromboxane synthetase inhibitors simultaneously for three days followed by a normal diet for one to 14 days. At the end of experimental periods in vivo and in vitro intestinal permeabilities to ${ }^{51} \mathrm{Cr}$-EDTA were measured, tissue was processed for histological examination, and mucosal myeloperoxidase assay performed. A further group of animals was fed indomethacin $8 \mathrm{mg} / \mathrm{kg}$ day for three days and then a normal diet for periods from one to 28 days. At the end of this period thromboxane synthetase inhibitor (UK 49883 or dazmegrel) was administered for three days with normal diet. The day after the last dose of thromboxane synthetase inhibitor in vivo or in vitro permeabilities to ${ }^{51} \mathrm{Cr}$-EDTA were measured. To ensure that the mucosal lesions had developed, immediately before the start of the thromboxane syilthetase inhibitor treatment period a limited laparotomy was performed.

\section{HISTOLOGY}

The animals were anaesthetised with methoxyflurane and sacrificed by cervical dislocation. A piece of ileum was removed $20 \mathrm{~cm}$ from the ileocaecal valve from control and experimental animals. In animals treated with indomethacin that developed macroscopical lesions, histological sections were prepared from these lesions. From the sequentially treated group - that is, indomethacin followed by thromboxane syn- thetase inhibitors - at the time of limited laparotomy the macroscopically abnormal areas were marked with coloured silk. After treatment with thromboxane synthetase inhibitor, histological sections were prepared from these areas of intestine. The tissue was fixed and stained with haematoxylin and eosin as previously described. ${ }^{17}$ The microscopical appearance was interpreted by a pathologist who was blind to the treatment status of the animal.

\section{Results}

EXPERIMENTALLY INDUCED ENTEROPATHY

Daily average food intake for animals with indomethacin-induced enteropathy and control animals is shown in Figure 1. There was no significant difference between the two groups. Body weights for animals with indomethacininduced enteropathy and control animals are shown in Figure 2. The weights of the animals with enteropathy were significantly less than that of the control animals at eight weeks $(\mathrm{p}<0.05$, 2 way analysis of variance).

IN VITRO AND IN VIVO ${ }^{51} \mathrm{Cr}$-EDTA PERMEABILITY ${ }^{51} \mathrm{Cr}$-EDTA uptake was directly proportional to wet weight of intestine for a range from 1 to $25 \mathrm{mg}(\mathrm{r}=0.83, \mathrm{p}<0.01)$. The in vitro and in vivo permeability in indomethacin-treated rats was significantly greater than in control animals (Table I). Indomethacin treatment did not affect the in vitro permeability of jejunal mucosal fragments, showing that the effect was specific to the ileum.

\section{STEROID AND SULPHASALAZINE}

The in vitro and in vivo ${ }^{51} \mathrm{Cr}$-EDTA uptakes are shown in Table I under the different experimental conditions. The in vitro and in vivo permeabilities were significantly reduced in indomethacin-treated animals who simultaneously or sequentially received prednisolone $(\mathrm{p}<0.01,2$ way analysis of variance) or sulphasalazine $(p<0.05,2$ way analysis of variance) compared to those receiving indomethacin alone.

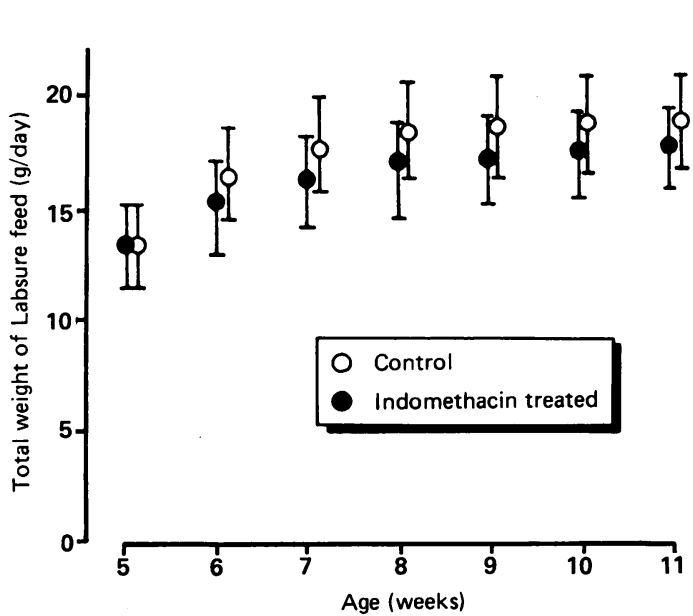

Figure 1: Daily average food intake (g/day on ad libitum diet) in control and indomethacin-treated rats. Values are mean $(S E)(n=5)$

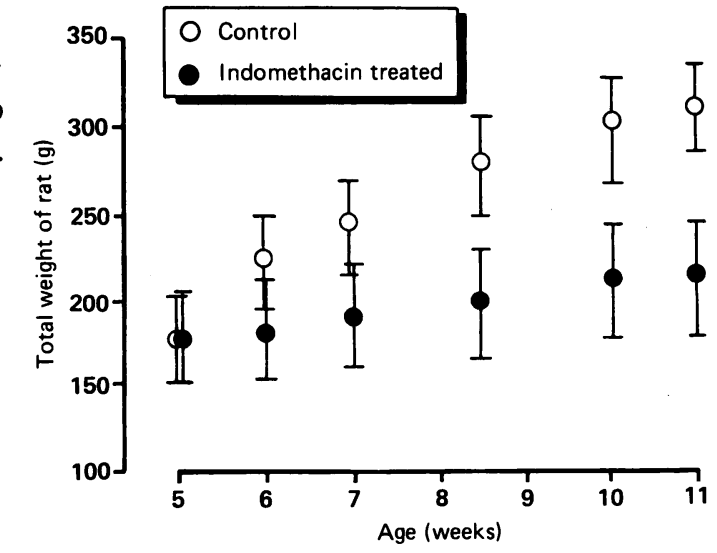

Figure 2: Mean body weights of control and indomethacintreated rats. Values are mean $(S E)(n=5)$. Indomethacintreated rats. Values are mean $(S E)(n=5)$. Indomethacinvariance) than controls ( $p<0.05$ at 8 to 11 weeks, 4 to 7 weeks after start of experiment). 
TABLE I Intestinal permeability of control, NSAID-treated, and drug-treated animals: in vitro and in vivo ${ }^{\mathrm{S} C} \mathrm{Cr}-\mathrm{EDTA}$ activity (mean (SE)) (12 animals in each group)

\begin{tabular}{|c|c|c|c|c|c|c|c|c|}
\hline & $\begin{array}{l}\text { Control } \\
\text { (untreated) }\end{array}$ & $\begin{array}{l}\text { Indomethacin } \\
(8 \mathrm{mg} / \mathrm{kg})\end{array}$ & $\begin{array}{l}\text { Sulphasalazine } \\
(20 \mathrm{mg} / \mathrm{kg})\end{array}$ & $\begin{array}{l}\text { Prednisolone } \\
(0.5 \mathrm{mg} / \mathrm{kg})\end{array}$ & $\begin{array}{l}\text { Indomethacin+ } \\
\text { sulphasalazine } \\
\text { simultaneously }\end{array}$ & $\begin{array}{l}\text { Indomethacint } \\
\text { prednisolone } \\
\text { simultaneously }\end{array}$ & $\begin{array}{l}\text { Indomethacint } \\
\text { sulphasalazine } \\
\text { sequentially }\end{array}$ & $\begin{array}{l}\text { Indomethacin+ } \\
\text { prednisolone } \\
\text { sequentially }\end{array}$ \\
\hline $\begin{array}{l}\text { In vitro permeability ( } \mu \text { l me } \\
\mathrm{A}=\text { posttreatment day } 3 \\
\mathrm{~B}=\text { posttreatment day } 7\end{array}$ & $\begin{array}{l}\operatorname{dium} / m g \text { tissue }): \\
0.104(0.02) \\
0.106(0.02)\end{array}$ & $\begin{array}{l}0.168(0.02)^{\star} \\
0.172(0.02)^{\star}\end{array}$ & $\begin{array}{l}0 \cdot 108(0.02) \\
0 \cdot 11(0.02)\end{array}$ & $\begin{array}{l}0 \cdot 106(0.01) \\
0 \cdot 112(0.01)\end{array}$ & $\begin{array}{l}0.114(0.02) \\
0.116(0.02)\end{array}$ & $\begin{array}{l}0.116(0.02) \\
0.108(0.02)\end{array}$ & $\begin{array}{l}0.148(0.02) \dagger \\
0.152(0.03) \dagger\end{array}$ & $\begin{array}{l}0.122(0.02) \dagger \\
0.12(0.02) \dagger\end{array}$ \\
\hline $\begin{array}{l}\text { In vivo permeability }(\% \text { uri } \\
\mathrm{A}=\text { posttreatment day } 3 \\
\mathrm{~B}=\text { posttreatment day } 7\end{array}$ & $\begin{array}{l}\text { e/total recovered } \\
3 \cdot 9(1 \cdot 3) \\
4 \cdot 0(1 \cdot 4)\end{array}$ & $\begin{array}{l}\text { tivity): } \\
12 \cdot 1(1 \cdot 5)^{\star} \\
12 \cdot 9(1 \cdot 7)^{\star}\end{array}$ & $\begin{array}{l}4.2(0.9) \\
4.3(1 \cdot 0)\end{array}$ & $\begin{array}{l}4 \cdot 1(0.07) \\
4 \cdot 3(0.08)\end{array}$ & $\begin{array}{l}3.9(0.08) \\
3.8(0.07)\end{array}$ & $\begin{array}{l}3.9(0.09) \\
3.9(0.8)\end{array}$ & $\begin{array}{l}8 \cdot 3(1 \cdot 1) \dagger \\
8 \cdot 4(1 \cdot 1) \dagger\end{array}$ & $\begin{array}{l}6 \cdot 1(1 \cdot 0) \dagger \\
6 \cdot 2(1 \cdot 1) \dagger\end{array}$ \\
\hline
\end{tabular}

Statistics by 2 way analysis of variance: ${ }^{\star} \mathrm{p}<0.001$ compared with untreated controls; $\mathrm{tp}<0.01$ compared with indomethacin alone.

TABLE II Tissue myeloperoxidase activity ( $\mathrm{mU} / \mathrm{mg}$ protein) for indomethacin-treated animals (mean (SE)) (12 animals in each group)

\begin{tabular}{|c|c|c|c|c|c|c|c|c|}
\hline & $\begin{array}{l}\text { Control } \\
\text { (untreated) }\end{array}$ & $\begin{array}{l}\text { Indomethacin } \\
(8 \mathrm{mg} / \mathrm{kg})\end{array}$ & $\begin{array}{l}\text { Sulphasalazine } \\
(20 \mathrm{mg} / \mathrm{kg})\end{array}$ & $\begin{array}{l}\text { Prednisolone } \\
(0.5 \mathrm{mg} / \mathrm{kg})\end{array}$ & $\begin{array}{l}\text { Indomethacint } \\
\text { sulphasalazine } \\
\text { simultaneously }\end{array}$ & $\begin{array}{l}\text { Indomethacint } \\
\text { prednisolone } \\
\text { simultaneously }\end{array}$ & $\begin{array}{l}\text { Indomethacin+ } \\
\text { sulphasalazine } \\
\text { sequentially }\end{array}$ & $\begin{array}{l}\text { Indomethacin }+ \\
\text { prednisolone } \\
\text { sequentially }\end{array}$ \\
\hline $\begin{array}{l}A=\text { posttreatment day } 3 \\
B=\text { posttreatment day } 7\end{array}$ & $\begin{array}{l}10.8(0.4) \\
10.9(0.5)\end{array}$ & $\begin{array}{l}17 \cdot 2(0 \cdot 5)^{\star} \\
19 \cdot 8(0 \cdot 7)^{\star}\end{array}$ & $\begin{array}{l}10 \cdot 2(0 \cdot 5) \\
10 \cdot 3(0 \cdot 4)\end{array}$ & $\begin{array}{l}8.9(0.5) \\
9 \cdot 1(0.6)\end{array}$ & $\begin{array}{l}11 \cdot 2(0 \cdot 5) \\
12 \cdot 1(0 \cdot 5)\end{array}$ & $\begin{array}{l}11 \cdot 1(0 \cdot 5) \\
11 \cdot 5(0.5)\end{array}$ & $\begin{array}{l}12.1(0.6) \dagger \\
12.6(0.5) \dagger\end{array}$ & $\begin{array}{l}11.8(0.7) \dagger \\
11.4(0.5) \dagger\end{array}$ \\
\hline
\end{tabular}

Statistics by 2 way analysis of variance: ${ }^{\star} \mathrm{p}<0.001$ compared with untreated controls; $\mathrm{tp}<0.01$ compared with indomethacin alone.

TABLE III In vitro and in vivo ${ }^{51} \mathrm{Cr}$-EDTA permeability for indomethacin-and thromboxane synthetase inhibitor-treated animals (mean (SE)) (12 animals in each group)

\begin{tabular}{|c|c|c|c|c|c|c|c|c|}
\hline & $\begin{array}{l}\text { Control } \\
\text { (untreated) }\end{array}$ & $\begin{array}{l}\text { Indomethacin } \\
(8 \mathrm{mg} / \mathrm{kg})\end{array}$ & $\begin{array}{l}\text { Dazmegrel } \\
(25 \mathrm{mg} / \mathrm{kg})\end{array}$ & $\begin{array}{l}U K 49883 \\
(2 \cdot 5 \mathrm{mg} / \mathrm{kg})\end{array}$ & $\begin{array}{l}\text { Indomethacint } \\
\text { dazmegrel } \\
\text { simultaneously }\end{array}$ & $\begin{array}{l}\text { Indomethacint } \\
\text { UK } 49883 \\
\text { simultaneously }\end{array}$ & $\begin{array}{l}\text { Indomethacint } \\
\text { dazmegrel } \\
\text { sequentially }\end{array}$ & $\begin{array}{l}\text { Indomethacin+ } \\
\text { UK } 49883 \\
\text { sequentially }\end{array}$ \\
\hline $\begin{array}{l}\text { In vitro activity }(\mu \text { l mediu } \\
\mathrm{A}=\text { posttreatment day } 1 \\
\mathrm{~B}=\text { posttreatment day } 3 \\
\mathrm{C}=\text { posttreatment day } 7\end{array}$ & $\begin{array}{l}\text { mg tissue): } \\
0 \cdot 108(0 \cdot 02) \\
0 \cdot 104(0 \cdot 02) \\
0 \cdot 106(0 \cdot 01)\end{array}$ & $\begin{array}{l}0.162(0.02)^{\star} \\
0 \cdot 168(0.02)^{\star} \\
0.172(0.02)^{\star}\end{array}$ & $\begin{array}{l}0 \cdot 106(0.02) \\
0 \cdot 104(0.02) \\
0 \cdot 11(0 \cdot 02)\end{array}$ & $\begin{array}{l}0 \cdot 110(0 \cdot 01) \\
0 \cdot 102(0 \cdot 02) \\
0 \cdot 112(0 \cdot 01)\end{array}$ & $\begin{array}{l}0.114(0.02) \\
0.112(0.02) \\
0.110(0.02)\end{array}$ & $\begin{array}{l}0.110(0.02) \\
0.116(0.02) \\
0.112(0.02)\end{array}$ & $\begin{array}{l}0.120(0.02) \dagger \\
0.124(0.02) \dagger \\
0.122(0.02) \dagger\end{array}$ & $\begin{array}{l}0.122(0.03) \dagger \\
0.124(0.02) \dagger \\
0.126(0.02) \dagger\end{array}$ \\
\hline $\begin{array}{l}\text { In vivo activity (\% urine/t } \\
\mathrm{A}=\text { posttreatment day } 3 \\
\mathrm{~B}=\text { posttreatment day } 7\end{array}$ & $\begin{array}{l}\text { l recovered acti } \\
3 \cdot 9(1 \cdot 3) \\
4 \cdot 0(1 \cdot 4)\end{array}$ & $\begin{array}{l}12 \cdot 1(1 \cdot 5)^{\star} \\
12 \cdot 9(1 \cdot 7)^{\star}\end{array}$ & $\begin{array}{l}4 \cdot 1(1 \cdot 2) \\
4 \cdot 2(1 \cdot 3)\end{array}$ & $\begin{array}{l}4 \cdot 1(1 \cdot 1) \\
4 \cdot 2(1 \cdot 2)\end{array}$ & $\begin{array}{l}4 \cdot 0(1 \cdot 1) \\
4 \cdot 0(1 \cdot 1)\end{array}$ & $\begin{array}{l}3 \cdot 9(1 \cdot 0) \\
4 \cdot 0(1 \cdot 2)\end{array}$ & $\begin{array}{l}6 \cdot 1(1 \cdot 5) \\
6 \cdot 4(1 \cdot 4)\end{array}$ & $\begin{array}{l}6 \cdot 2(1 \cdot 4) \\
6 \cdot 5(1 \cdot 5)\end{array}$ \\
\hline
\end{tabular}

Statistics by 2 way analysis of variance: ${ }^{\star} \mathrm{p}<0.001$ compared with untreated controls; $\nmid \mathrm{p}<0.01$ compared with indomethacin alone.

\section{ANTIBIOTIC TREATMENT}

The in vitro and in vivo ${ }^{51} \mathrm{Cr}$-EDTA permeabilities are shown for the various experiments with tetracycline (Figs 3 and 4). Indomethacin-treated animals who were pretreated or simultaneously

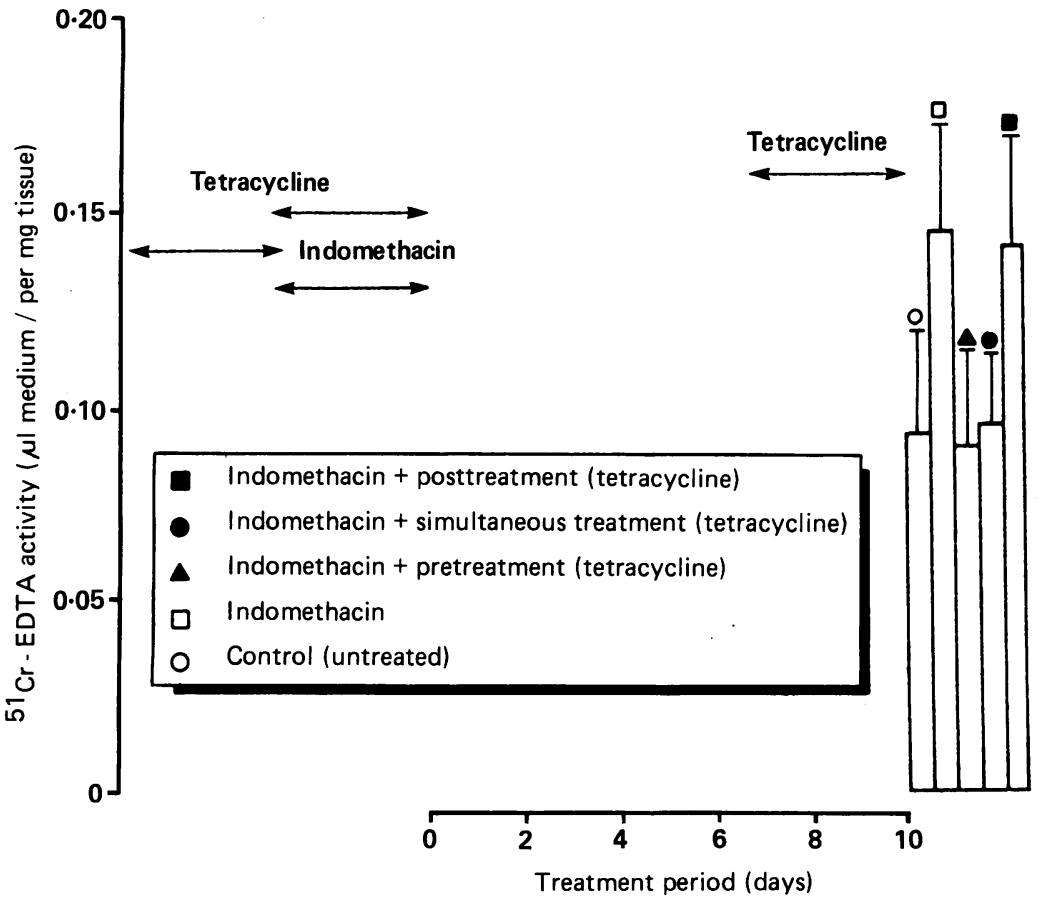

Figure 3: In vitro ${ }^{51} \mathrm{Cr}-\mathrm{EDTA}$ permeability in control rats and rats treated with indomethacin and indomethacin + tetracycline. Results are mean $(S E)(n=12)$ for control (untreated), indomethacin $8 \mathrm{mg} / \mathrm{kg}$; indomethacin + pretreatment with tetracycline $25 \mathrm{mg} / \mathrm{kg}$ for 3 days; indomethacin + tetracycline $25 \mathrm{mg} / \mathrm{kg}$ for 3 days; indomethacin followed by tetracycline $25 \mathrm{mg} / \mathrm{kg}$ for 3 days. Statistical analysis by 2 way analysis of variance shows that pretreated and simultaneously treated rats show no significant difference from controls $(p>0 \cdot 1)$ while posttreated rats show significantly increased permeability compared to controls $(p<0.01)$ but not significantly different from indomethacin-treated rats $(p>0 \cdot 1)$. treated with tetracycline did not differ significantly from untreated animals. Posttreatment with tetracycline had no effect on indomethacininduced increase in permeability.

MYELOPEROXIDASE ACTIVITY

The results of the myeloperoxidase assay are shown as change in absorbance per minute per gram of tissue in Table II. The indomethacintreated animals had a raised myeloperoxidase activity which was partially reversed by treatment with steroids $(\mathrm{p}<0.01)$ and sulphasalazine $(\mathrm{p}<0.02)$.

\section{THROMBOXANE SYNTHETASE INHIBITOR STUDIES}

\section{Dazmegrel and indomethacin}

The in vitro ${ }^{51} \mathrm{Cr}$-EDTA uptakes are shown in Table III under the different experimental conditions. The mucosal permeability of indomethacin-treated animals was significantly greater than in control animals. Furthermore, the permeability was not increased above control values in indomethacin-treated animals who simultaneously or sequentially received dazmegrel; dazmegrel alone had no effect on intestinal permeability.

The in vivo ${ }^{51} \mathrm{Cr}$-EDTA permeability measurements are shown in Table III. The in vivo mucosal permeability in indomethacintreated animals was significantly greater than in control animals. Furthermore, the permeability was not significantly increased in indomethacintreated animals who simultaneously or sequentially received dazmegrel. 


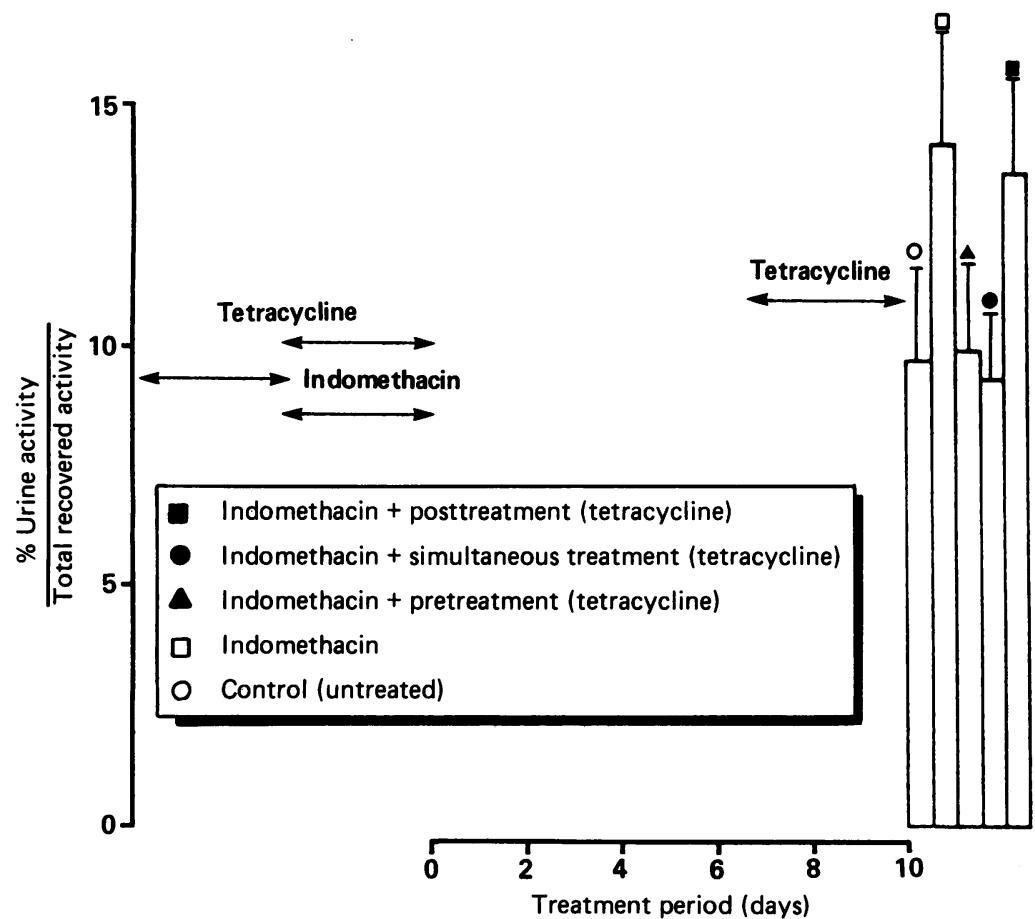

Figure 4: In vivo ${ }^{\text {II }} \mathrm{Cr}$-EDTA permeability in control rats and rats treated with indomethacin and indomethacin + tetracycline. Results are mean $(S E)(n=12)$ for control (untreated); indomethacin $8 \mathrm{mg} / \mathrm{kg}$; indomethacin + pretreatment with tetracycline $25 \mathrm{mg} / \mathrm{kg}$ for 3 days; indomethacin + tetracycline $25 \mathrm{mg} / \mathrm{kg}$ simultaneously for 3 days; indomethacin followed by tetracycline $25 \mathrm{mg} / \mathrm{kg}$ for 3 days. Statistical analysis by 2 way analysis of variance shows that pretreated and simultaneously treated rats show no significant difference from controls $(p>0 \cdot 1)$ while posttreated rats show significantly increased activity compared to controls $(p<0.01)$ but not significantly different from indomethacin-treated rats $(p>0 \cdot 1)$.

\section{Histology}

Small intestinal mucosal histology for indomethacin-treated animals showed adhesions between loops of bowel with inflammation in the serosal fat and abscess formation associated with mucosal inflammation and ulceration. Some animals treated with indomethacin and thromboxane synthetase inhibitors showed similar changes while others showed minimal mucosal inflammation. Thus, no definite histological pattern could be reliably identified.

\section{Myeloperoxidase activities}

The results of the myeloperoxidase assays are shown in Table IV. The indomethacintreated animals have a raised mucosal activity which is prevented when the thromboxane synthetase inhibitors are administered simultaneously with the indomethacin but only partially reversed when they are administered after indomethacin.

\section{Discussion}

Much previous work exists on possible animal models for Crohn's disease. Mitchell and Rees, ${ }^{16}$ in their mouse footpad model, found that a significant proportion of mice receiving homogenates prepared from Crohn's disease tissues showed the typical focal granulomas of Crohn's disease. The disadvantages of this model are that the granulomas evolve fully only six to 24 months after inoculation and that no response was seen with sulphasalazine, glucocorticoids, or immunosuppressive treatment, which makes the model unsuitable for pharmacological studies. In addition, assessment is subjective and qualitative based on histological appearance.

The current model of NSAID enteropathy in rats was described initially 20 years ago. ${ }^{1718}$ Subsequently, it has been shown to have a clinical counterpart in NSAID enteropathy in humans, ${ }^{19}$ in particular there are many clinical and histological similarities between the rat model and inflammatory bowel disease. The pathogenic mechanism was thought to be prostaglandin related and a temporal relation between cyclo-oxygenase inhibition and the gastrointestinal damage induced by indomethacin in the rat has been shown..$^{20}$ Local changes in intestinal microflora were also thought to be important and this was confirmed by reports that germ free animals do not develop the lesion readily. ${ }^{21}$ In large doses many NSAIDs cause small intestinal inflammation in the experimental animal which may lead to ulceration, perforation, and death. Thus the postulated mechanism is that altered mucosal prostaglandin synthesis compromises intestinal integrity, resulting in mucosal susceptibility to luminal toxins with the inflammation reflecting the mucosal response to the bacterial products. It has now been shown in a series of studies that approximately $70 \%$ of patients on chronic NSAID treatment for arthritic diseases have small intestinal inflammation similar to that seen in the experimental animal and on discontinuing the drug the inflammation may persist for up to 16 months. ${ }^{19}$

The present experiments further validate the indomethacin-treated rat model with particular reference to the early permeability changes. The main indices of activity are ${ }^{51} \mathrm{Cr}$-EDTA in vitro and in vivo permeability measurements and mucosal myeloperoxidase activities. The in vivo ${ }^{51} \mathrm{Cr}$-EDTA test is useful to quantitate permeability changes along the whole of the small intestine. The in vitro ${ }^{51} \mathrm{Cr}$-EDTA measurements assess more local permeability changes: they represent an index which provides useful confirmation of the in vivo changes. The importance of the in vitro ${ }^{\text {s1 }} \mathrm{Cr}$-EDTA permeability is to cover the main limitation of the ${ }^{\mathrm{I}} \mathrm{Cr}$-EDTA in vivo absorption test - that is, the in vivo test does not indicate the exact site of altered permeability

TABLE IV Mucosal myeloperoxidase activities ( $m U / m g$ tissue) in indomethacin-and thromboxane synthetase inhibitor-treated animals (mean (SE)) (12 animals in each group)

\begin{tabular}{|c|c|c|c|c|c|c|c|c|}
\hline & $\begin{array}{l}\text { Control } \\
\text { (untreated) }\end{array}$ & $\begin{array}{l}\text { Indomethacin } \\
(8 \mathrm{mg} / \mathrm{kg})\end{array}$ & $\begin{array}{l}\text { Dazmegrel } \\
(25 \mathrm{mg} / \mathrm{kg})\end{array}$ & $\begin{array}{l}U K 49883 \\
(2.5 \mathrm{mg} / \mathrm{kg})\end{array}$ & $\begin{array}{l}\text { Indomethacin+ } \\
\text { dazmegrel } \\
\text { simultaneously }\end{array}$ & $\begin{array}{l}\text { Indomethacin+ } \\
\text { UK } 49883 \\
\text { simultaneously }\end{array}$ & $\begin{array}{l}\text { Indomethacint } \\
\text { dazmegrel } \\
\text { sequentially }\end{array}$ & $\begin{array}{l}\text { Indomethacin+ } \\
\text { UK } 49883 \\
\text { sequentially }\end{array}$ \\
\hline $\begin{array}{l}A=\text { posttreatment day } 1 \\
B=\text { posttreatment day } 3 \\
C=\text { posttreatment day } 7\end{array}$ & $\begin{array}{l}10 \cdot 7(0.4) \\
10 \cdot 8(0.4) \\
10 \cdot 8(0.4)\end{array}$ & $\begin{array}{l}17 \cdot 0(0 \cdot 3)^{\star} \\
17 \cdot 4(0 \cdot 6)^{\star} \\
18 \cdot 6(0 \cdot 7)^{\star}\end{array}$ & $\begin{array}{l}10 \cdot 3(0 \cdot 3) \\
10 \cdot 9(0 \cdot 5) \\
10 \cdot 7(0 \cdot 3)\end{array}$ & $\begin{array}{l}10 \cdot 3(0 \cdot 5) \\
10 \cdot 5(0 \cdot 5) \\
10 \cdot 5(0 \cdot 3)\end{array}$ & $\begin{array}{l}11 \cdot 1(0 \cdot 3) \\
10 \cdot 9(0 \cdot 6) \\
11 \cdot 2(0 \cdot 5)\end{array}$ & $\begin{array}{l}10 \cdot 9(0 \cdot 4) \\
11 \cdot 1(0 \cdot 4) \\
11 \cdot 1(0 \cdot 5)\end{array}$ & $\begin{array}{l}13.9(0 \cdot 6) \dagger \\
13 \cdot 1(0 \cdot 6) \dagger \\
12 \cdot 9(0.6) \dagger\end{array}$ & $\begin{array}{l}13 \cdot 7(0 \cdot 5) \dagger \\
13 \cdot 3(0 \cdot 5) \dagger \\
13 \cdot 3(0 \cdot 6) \dagger\end{array}$ \\
\hline
\end{tabular}

Statistics by 2 way analysis of variance: ${ }^{\star} \mathrm{p}<0.001 ; \mathrm{tp}<0.01$. 
and the overall absorption could be affected by such variables as gastric emptying, luminal dilution, and intestinal transit time, as well as mucosal permeability. ${ }^{11}{ }^{22}$ Determination of the exact site of absorption is also crucial because the maximal effects of indomethacin occur in the mid-ileum: the jejunum is unaffected. This feature is thus a further important parallel in the role of the lesion as a model of inflammatory bowel disease. In vivo absorption studies alone would be inadequate to show this effect. Tissue myeloperoxidase was assayed as previous studies have shown that this is a sensitive marker of inflammatory cells within the mucosa, particularly in inflammatory bowel disease. ${ }^{23}$ Since the early changes are histologically non-specific, the myeloperoxidase levels are a useful way of quantifying the early inflammatory response.

This study investigated the initial lesion and has clearly shown both in vitro and in vivo enhanced mucosal permeability, increased tissue myeloperoxidase levels, and reduced weight gain while maintaining similar food intakes in NSAID-treated rats, all typical of patients with chronic inflammatory bowel disease. Previous work has shown that treatment with several antibiotics (bacitracin, neomycin, and polymyxin B) prevent the development of the small intestinal lesion in indomethacin-treated rats. ${ }^{2}$ Our studies confirm that the same is true of tetracycline. Treatment with tetracycline subsequent to the indomethacin treatment, however, does not heal the lesion. This might imply that intestinal microflora are important in the development, but may relate to the limited sensitivity of micro-organisms to tetracycline, but not the maintenance of the enteropathy. These studies also show that the lesion may be reversed with prednisolone and, to a lesser extent, with sulphasalazine treatment. Steroids are known to improve flare ups of Crohn's disease and it has recently been shown that treatment with sulphasalazine also improves permeability changes in patients with Crohn's disease. ${ }^{24}$ This is important since these results provide evidence that the lesion has similarities with Crohn's disease, although there are clear histological differences between NSAID enteropathy and classical Crohn's disease. Although clinical and therapeutic similarities to Crohn's disease do not equate necessarily to the same disease process, it is clear that in some patients NSAID enteropathy may be masquerading as Crohn's disease. The findings in this study provide some evidence why some patients in this category respond clinically to treatment for Crohn's disease. Earlier work from our laboratory showed that enteropathy induced by ethanol, cetrimide, or methotrexate caused increased in vivo ${ }^{51} \mathrm{Cr}$-EDTA permeability. Histological assessment showed non-specific inflammatory changes with increased crypt depth. Polymorphs were prominent in the lamina propria and occasional crypt abscesses were noted. ${ }^{2}$

The mechanism by which glucocorticoids and sulphasalazine have their effect is unclear, but it almost certainly involves a general reduction in inflammatory activity by stabilising lysosomal membranes and free radical activity. ${ }^{31}$ The data on myeloperoxidase levels support this concept. Modulation of intestinal arachidonic acid metabolism by sulphasalazine has also been proposed, and this also might explain the improvement of NSAID enteropathy. ${ }^{25} 26$

One pathogenetic mechanism for the development of NSAID enteropathy may be local changes in prostaglandin and arachidonic acid metabolism. ${ }^{9} 1027$ This hypothesis would provide a clear link between the findings in our experiments and the known properties of selective thromboxane synthetase inhibitors. There is a sensitive balance between the potent proaggregatory and vasoconstrictor thromboxane $\mathrm{A}_{2}$ $\left(\mathrm{TXA}_{2}\right)$ and the antiaggregatory prostacyclin $\left(\mathrm{PGI}_{2}\right)$ in the vascular endothelium. If indeed the vascular hypothesis is important in the pathogenesis of NSAID enteropathy, the feasibility of selective thromboxane synthetase inhibition will largely depend on whether endoperoxidases can be effectively diverted into prostacyclin or PGD2 formation, at least at sites of pathological platelet-vessel wall interaction. Changes in the prostaglandin/arachidonic acid system has also been implicated in the aetiology of inflammatory bowel disease. ${ }^{28-30}$ Finally, recent evidence from morphological studies in patients with Crohn's disease suggest a pathogenetic sequence of events: vascular injury, focal arteritis, fibrin deposition, arterial occlusion mainly at the level of the muscularis propria, followed by tissue infarction or neovascularisation. ${ }^{3}$ Although the trigger of indomethacininduced enteropathy is clearly different from Crohn's disease, the two diseases may share a final common pathway once vascular injury is established, thus explaining the similarities between NSAID-induced enteropathy and inflammatory bowel disease and also adding further support for the former being a valid model of the latter. ${ }^{32}$

Thromboxane synthetase inhibitors administered concurrently with indomethacin prevent the genesis of NSAID enteropathy. Furthermore, when there is a time delay between the two the intestinal permeability changes and tissue myeloperoxidase levels seem to return to normal. These results indicate that the biological effects of the indomethacin are being reversed rather than simple pharmacological antagonism occurring. Thromboxane synthetase inhibitors seem to reverse the acute permeability changes rather than the more chronic fibrous stricturing. The use of two structurally distinct thromboxane synthetase inhibitors strengthens the case for a thromboxane based mechanism and not an effect unique to dazmegrel alone.

Thus, new thromboxane synthetase inhibitors may provide exciting new treatment possibilities for reversing some of the changes of NSAIDinduced enteropathy. Such agents would be more useful in treating acute relapses for the disease and possibly preventing the onset of lesions rather than influencing chronic strictures. They may also have a role in the treatment of inflammatory bowel disease in general.

AKB is in receipt of an MRC Training Fellowship

1 Baneriee AK. NSAID enteropathy [Editorial]. Br Med f 1989; 293: $1539-40$. 
2 Bjarnason I, Smethurst PP, Levi AJ, Peters TJ. Intestinal permeability to "Cr-EDTA in rats with experimentally induced enteropathy. Gut 1985; 26: 579-85.

3 Wakefield AJ, Sawyer AM, Dhillon AP, et al. Pathogenesis of Crohn's disease: multifocal gastrointestinal infarction. Lancet 1989; ii: 1057-62.

4 Bjarnason I, Peters TJ. Helping the mucosa make sense of macromolecules. Gut 1986; 28: 1057-61.

5 Shorter RG, Huizenga GA, Spencer RJ. A working hypothesis for the etiology and pathogenesis of non-specific inflammafor the etiology and pathogenesis of non-specific int
tory bowel disease. Dig Dis Sci 1972; 72: 1027-37.

6 Bjarnason I, O'Morain C, Levi AJ, Peters TJ. Absorption of sichromium-labelled ethylene diamine tetraacetate in inflammatory bowel disease. Gastroenterology 1983; 85: 318-22.

7 Hollander D, Vadheim CM, Brettholtz E, et al. Increased intestinal permeability in patients with Crohn's disease and their relatives. A possible etiological factor. Ann Intern Med 1986; 105: 883-5.

8 Banerjee AK, Peters TJ. Crohn's or poisoning. Gut 1988; 29: 1152 .

9 Bjarnason I, Smethurst P, Fenn GC, Lee CE, Levi AJ. Misoprostol reduces indomethacin induced changes in human small intestinal permeability. Gastroenterology 1988; 94: 1937.

10 Bjarnason I, Smethurst P, Clarke P, Menzies JS, Levi AJ, Peters TJ. Effects of prostaglandins on indomethacin induced increased intestinal permeability in man. Scand $\mathcal{f}$ induced increased intestinal

11 Bjarnason I, Peters TJ. In vitro determination of small intestinal permeability: demonstration of a persistent defect in patients with coeliac disease. Gut 1984; 25 : 145-50.

12 Cronquist AG, Mackenzie J, Smith T. A high resolution bulk sample counter with variable geometry. Int $\mathcal{F}$ Appl Radiat Isot 1975; 26: 89-91.

13 Cross PE, Dickinson RP, Parry MJ, Randall MJ. Selective thromboxane synthetase inhibitors 2: 3-(IH-Imidazol-1thromboxane synthetase inhibitors 2: 3-(IH-Imidazol-1yl methyl)-2-methyl -IH-indole-1-propan

14 Cross PE, Dickinson RP. The design of selective thromboxane synthetase inhibitors. Spec Publ Roy Soc Chem 1984; 50: 268-85

15 Bradley PP, Christensen RD, Rothstein G. Cellular and extracellular myeloperoxidase in pyogenic inflammation. Blood 1982; 60: 618-22.

16 Mitchell DN, Rees RJW. Agent transmissible from Crohn's disease tissue. Lancet 1970; ii: 168-71.

17 Kent TH, Cardelli RM, Stamler FW. Small intestinal ulcers and intestinal flora in rats given indomethacin. Am F Patho 1969; 54: 237-45.
18 Fang W-F, Broughton A, Jacobsen ED. Indomethacin induced intestinal inflammation. Am $\mathcal{F}$ Dig Dis 1977; 22: 749-60.

19 Bjarnason I, Zanelli G, Smith T, et al. Non-steroidal antiinflammatory drug-induced intestinal inflammation in humans. Gastroenterology 1987; 93: 480-9.

20 Whittle BJR. Temporal relationship between cyclooxygenase inhibition, as measured by prostacyclin biosynthesis, and the gastrointestinal damage induced by indomethacin in the rat. Gastroenterology 1981; 80: 94-8.

21 Robert A, Asano T. Resistance of germ free rats to indomethacin induced intestinal lesions. Prostaglandins 1977;14: methacin

22 Bjarnason I, Ward K, Peters TJ. The leaky gut of alcoholism: possible route of entry for toxic compounds. Lancet 1984; i: 179-82.

23 Kane SP, Vincenti AC. Mucosal enzymes in human inflammatory bowel disease with reference to neutrophil granulocytes as mediators of tissue injury. Clin Sci 1979; 57: 295-303.

24 Bjarnason I, Zanelli G, Teahon K, Smethurst P, Levi AJ. Treatment of small intestinal Crohn's disease with sulphasalazine. Gastroenterology 1988; 94: A38.

25 Hawkey CJ, Boughton-Smith NK, Whittle BJR. Modulation of human colonic arachidonic acid metabolism by sulfasalazine. Dig Dis Sci 1985; 30: 1161-5.

26 Ligumsky M, Karmeli F, Sharon P, Zor U, Cohen F, Rachmilewitz D. Enhanced thromboxane $A_{2}$ and prostacyclin production by cultured rectal mucosa in ulcerative colitis and its inhibition by steroids and sulfasalazine. Gastroenterology 1981; 81: 444-9.

27 Whittle BJR. Temporal relationship between cyclo-oxygenase inhibition, measured as prostacyclin biosynthesis and gastrointestinal damage induced by indomethacin in the rat. Gastroenterology 1981;80: 94-8.

28 Boughton-Smith NK, Whittle BJR. Increased metabolism of arachidonic acid in an immune model of colitis in guineapigs. Br J Pharmacol 1985; 86: 439-46.

29 Boughton-Smith NK, Wallace JL, Morris GP, Whittle BJR. Evaluation of the role of arachidonic acid metabolites in a rat Evaluation of the role of arachidonic acid metabolites in a rat
model of Crohn's disease. Gastroenterology 1985; 88: A1332.

30 Sharon P, Stenson WF. Metabolism of arachidonic acid in acetic acid colitis in rats. Similarity to human inflammatory bowel disease. Gastroenterology 1984; 88: 55-63.

31 Williams SG, Hallett MB. The reaction of 5-aminosalicylate with hypochlorite - implications for its mode of action in inflammatory bowel disease. Biochem Pharmacol 1989; 38: 149-54.

32 Banerjee AK, Peters TJ. Pathogenesis of Crohn's disease. Lancet 1989; ii: 1459-60. 


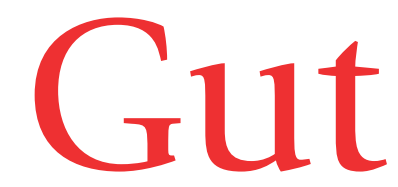

\section{Editorial}

\section{Retractions in Gut 10 years after publication}

It is with great regret that I include in this issue of the journal a retraction order for a paper authored by Dr Anjan Banerjee and Professor Tim Peters, which was published in Gut in 1990 when they were employed by King's College Hospital. Dr Banerjee wrote to me immediately following the decision by the Professional Conduct Panel of the General Medical Council (GMC) that he had been found guilty of serious professional misconduct and had been suspended for a period of 12 months. He indicated that he wished to retract the paper written by himself and Professor Tim Peters, "Experimental non-steroidal anti-inflammatory drug induced enteropathy in the rat - similarities to inflammatory bowel disease and effect of thromboxane synthetase inhibitors" (Gut 1990;31:1358-64) in which it was judged that he had falsified data. He also indicated that he wished to retract an abstract "Sulphasalazine reduces indomethacin induced changes in small intestinal permeability in man" (Banerjee A, Sherwood R, Rennie JA, Peters TJ. Gut 1990;31:A593) which had been published in Gut as part of the proceedings of the Spring British Society of Gastroenterology (BSG) meeting in Warwick 1990. However, Dr Banerjee and colleagues had indicated to the BSG that they wished to withdraw this abstract before the meeting took place and, although it was not presented at the meeting, the copy had already gone to press and therefore appeared in the journal. Thus for 10 years these reports, now deemed to contain falsified data, have remained within the biomedical literature.

This is clearly a personal tragedy for the authors, and has been potentially harmful to the development of scientific ideas which could have ultimately affected patient care. This case, however, perhaps raises more questions than answers. Why has it taken a decade before the record has been put straight? I believe it is true to say that rumours about this case had rattled around the corridors of a number of institutions for many years. Some members of the BSG are thought to have known of the allegations, as did some colleagues at Northwick Park Hospital, King's College Hospital Medical School, and some members of staff at the University of London. Why was this not fully explored in the early 1990s?

An internal inquiry was held at King's College Hospital Medical School which apparently reported in 1991. It is alleged that the inquiry produced evidence to suggest that Banerjee's research findings from 1988-91 were "at best unreliable and in many cases spurious". "However no action was taken, even though it could be argued that the case should have been reported to the GMC at that stage. It became clear at Banerjee's recent hearing at the GMC that his laboratory workbook, an important item of primary evidence, went missing after the inquiry and was probably destroyed by the authorities at King's. In retrospect, this is a disaster and does nothing to increase public confidence in the ability of the medical profession to regulate itself. For the man in the street, this can only be viewed as a "cover up".

How did this story eventually come to light? As in many other cases of research fraud it is the persistence of a "whistle blower" that enables the case to be brought into the public domain. Peter Wilmshurst, consultant cardiologist in Shrewsbury, wrote an article in The Lancet in 1997 which he entitled "The code of silence". ${ }^{1} \mathrm{He}$ wrote about his personal experiences of detecting and reporting research misconduct, one of which was the Banerjee case. The case description was "coded" for legal reasons but for those who were aware of the circumstances it was easily recognisable. The main thrust of the piece was the failure of the profession to investigate miscreants who had breached the rules of research ethics. In particular it was the closing of ranks, often involving senior members of the profession, that drove him on. Wilmshurst's commitment to outing fraudsters began in his early days as a clinical research fellow at a London Teaching Hospital where he experienced first hand corruption in clinical research. I understand from Peter Wilmshurst that he has reported other cases to the GMC which are still waiting to be heard.

This could sound like a satisfactory ending to an otherwise sad story. However, a number of issues remain unresolved. As editor of the journal in which Banerjee published his fraudulent work, I am responsible for issuing a retraction notice in the journal-a request which came promptly from the author following the GMC judgement. However it is extremely difficult to effectively erase an article from the published literature as the March and November 1990 issues of Gut will remain on library shelves for many decades to come without any indication that the Banerjee paper is fraudulent. In addition, we know that retracted papers continue to be cited after retraction almost invariably without reference to the falsehoods that are contained therein. ${ }^{2}$ If publication of scientific material becomes solely electronic, only then will it be possible to completely erase a paper and put the record straight.

Another issue is the delay that has occurred in bringing this case to the GMC. Intuitively most of us would believe that it would be preferable to deal with cases of research fraud promptly to limit the damage that false biomedical data might cause and to minimise the risk that further misdemeanours might be committed. Banerjee had already been suspended earlier in 2000 by his NHS Trust for, I understand, a totally different reason and has recently resigned from this post. Whether earlier resolution of the research misconduct case would have influenced this other issue remains a matter for speculation.

Unfortunately the case does not rest here. Banerjee's supervisor at the time he produced the fraudulent work, Professor Tim Peters, is also to appear before the GMC in 
early 2001 when his role in the affair will presumably be examined. ${ }^{3}$ Finally, and perhaps most important of all, it must be determined what happened following the internal enquiry of the Banerjee case at King's College Hospital Medical School in 1991. If Banerjee's work-as it is alleged-was found to be questionable at that time, why did the Dean of the day not refer the case to the GMC immediately? Why was the Gut paper not retracted in 1991, and why did Banerjee's supervisor remain associated with the work when other collaborators withdrew their names from the paper? It is likely that answers to all or some of these questions will come out of Professor Peters's GMC hearing; perhaps the GMC will have more work to do as the story evolves even further.

There is yet another matter still to be resolved. Data included in the retracted Gut paper allegedly form part of Banerjee's Master of Surgery thesis awarded by the University of London in $1991 .^{2}$ I tried to obtain a copy of the thesis from the University to verify whether this was indeed the case, but it was missing from the shelves, apparently out on an "inter-library loan". I was advised to try the library at St Thomas's. Another whistle blower (not Wilmshurst) apparently advised the University of London at the time, in writing, alleging falsification of the thesis, but was subsequently instructed to withdraw the letter with warnings that this might damage future career prospects. This story is almost too difficult to believe; it is perhaps surprising that this additional problem was not dealt with at the recent GMC hearing.

The Banerjee case illustrates a number of important deficiencies in the way in which we handle alleged cases of research misconduct in the UK. Firstly, it is evident that it is relatively simple to fabricate data and get it published in a reputable medical journal. In the majority of cases it will be virtually impossible for reviewers and editors to identify fraudulent material. Detection in this case, and in many others will almost always depend on the willingness of a vigilant whistle blower to speak out. There is little to gain for whistle blowers, particularly when their comments fall on deaf ears, or they are threatened with professional extinction. Secondly, the case demonstrates the potential weakness of the internal inquiry. Although it is unclear as to the location of the final resting place of the King's Banerjee Report, it is alleged that its findings were not in Banerjee's favour. ${ }^{1}$ It then took almost a decade and the persistent efforts of an external whistle blower, who had no conflicting interests, to bring the case to the GMC. This cannot be regarded as a satisfactory state of affairs and will do nothing to reassure the public that the medical profession is still fit to self regulate. The case also shows the importance of the role of the research supervisor as a custodian of research quality. When it was clear in 1991 that Banerjee's work was suspect, why did he not withdraw his support and insist on an external review by the GMC?

This case, and indeed many others considered by the Committee for Publication Ethics (COPE) ${ }^{45}$ and probably others still in the GMC pipeline, convinces me that the procedures currently in place in the UK are inadequate to deal with many of the alleged cases of research misconduct. COPE has campaigned for more than three years for an independent body to consider such cases. ${ }^{6}$ Although many Universities and Medical Schools have written guidance as to how to pursue an internal review, I have concerns that a lack of independence may inhibit action of the naturally reluctant whistle blower and not provide appropriate protection when required. In October 1999 a consensus conference was held at the Royal College of Physicians in Edinburgh on Misconduct in Biomedical Research. The consensus panel recommended that a National Panel should be established which would develop and promote models of good practise for local implementation, provide assistance with the investigation of alleged research misconduct, and collect, collate, and publish information on the incidence of research misconduct. Although discussions have taken place and a report is said to be in preparation, no clear action has at yet become apparent to those of us on the outside. ${ }^{7}$ Even if such an advisory panel is established will it really have the teeth to ensure that we do not have a re-run of the Banerjee case? I have my doubts. ${ }^{8}$ What COPE is proposing is not new. The USA, Nordic countries, and others have had external agencies in place to deal with alleged cases of research misconduct for almost 10 years $^{9}$; why is the UK lagging behind? One is reminded of the fact that it took 20 years longer to establish Research Ethics Committees in Britain than it did in the USA! $!^{10}$

MICHAEL J G FARTHING Editor

fanuary 2001

1 Wilmshurst P. The code of silence. Lancet 1997;349:567-9.

2 Ferriman A. Consultant suspended for research fraud. BMF 2000;321:1429.

3 Budd JM, Sievert ME, Schultz TR. Phenomena of retraction. fAMA 1998; 280:296-7.

4 Committee on Publication Ethics. Annual Report 1998. London: BMJ Publishing Group, 1998.

5 Committee on Publication Ethics. Annual Report 1999. London: BMJ Publishing Group, 1999.

6 Farthing MJG. An editor's response to fraudsters. BMf 1998;316:1729-31. 7 White C. Plans for tackling research fraud may not go far enough. BMF 2000;321:1487.

8 Farthing M, Horton R, Smith R. UK's failure to act on research misconduct. Lancet 2000;356:2030.

9 Nylenna M, Andersen D, Dahlquist G, et al. Handling of scientific dishonesty in the Nordic countries. Lancet 1999;354:57-61.

10 Doyal L, Tobias JS, Eds. Informed consent in medical research. London BMJ Publishing Group, 2000.

\section{Retraction}

Gut is retracting the paper by AK Banerjee and TJ Peters, "Experimental non-steroidal anti-inflammatory drug induced enteropathy in the rat-similarities to inflammatory bowel disease and effect of thromboxane synthetase inhibitors" (Gut 1990;31:1358-64) and the abstract AK Banerjee, R Sherwood, JA Rennie and TJ Peters, "Sulphasalazine reduces indomethacin induced changes in small intestinal permeability in man" (Gut 1990;31:A593) at the request of Dr Banerjee. At the end of November 2000, the General Medical Council found Dr Banerjee guilty of serious professional misconduct and suspended him for 12 months. Both articles were deemed to contain information which was deliberately falsified. 